\title{
Stock Market's Reaction to Self-Disclosure of Environmental Administrative Penalties: an Empirical Study in China
}

\author{
Xiangan Ding*, Ying Qu**, Mohsin Shahzad \\ School of Economics and Management, Dalian University of Technology, Dalian, China
}

Received: 31 October 2019

Accepted: 29 February 2020

\begin{abstract}
For a listed company the information about self-disclosing its environmental penalty will provide investors with reliable sources to observe its environmental situation. This study, employing the event study method, examines the stock market's reaction before and after its environmental penalty announcement. The impacts of environmental penalties on companies' abnormal returns during the observation period are evaluated as well. The findings reveal that the accumulative abnormal returns of penalized companies will drop before the environmental penalty announcements. Besides, selfdisclosing the environmental penalty will ease the negative impacts on their abnormal returns, and the disclosure of detailed rectification measures and the impacts of penalty in the announcements will increase their abnormal returns as opposed to bring further damage to their stock market returns. Our results suggest that the self-disclosure of penalty information prevents the decline of stock market returns, which implies that self-disclosure has a positive effect on companies' reactions in terms of market value.
\end{abstract}

Keywords: self-disclosure, environmental administrative penalty, penalty announcements, stock market's reaction, event study

\section{Introduction}

Severe environmental degradation out of the rapid economic growth after the implementation of reform and opening-up policy in China has drawn considerable attention at home and abroad since 1978 [1, 2]. How to effectively control environmental pollution has been the focus of current policy and societal discourse. Environmental information disclosure is also considered

\footnotetext{
*e-mail: dingxiangan@mail.dlut.edu.cn
} **e-mail: quying@dlut.edu.cn an effective way to achieve pollution reduction. Companies are required to make their environmental violations available to the public to provide investors with complete information, which enables investors to adjust their investment from companies involved with scandals to green and environmentally friendly companies.

The Chinese government started to improve its environmental regulation system and take information disclosure as an effective approach to regulating listed companies. In 2006, China's Securities Regulatory Commission released the Regulation on Information Disclosure of Listed Companies to require those 
companies which received major administrative penalties to issue the penalty announcement to the public. According to the Guidelines of Environmental Information Disclosure released in 2010, listed companies are required to disclose the contents, solutions, and impacts of the penalty in the interim announcements after they received environmental penalties. In 2016, the Guidelines for Establishing the Green Financial System were released jointly by seven ministerial agencies including the People's Bank of China and the National Development and Reform Commission. The guidelines proposed strengthening the requirements of environmental information disclosure, to establish and improve the mandatory system for listed companies to disclose environmental information to facilitate the development of green finance. However, such regulations or guidelines are not legally binding texts. Some listed companies punished by environmental protection departments did not disclose their penalty information. What will the stock market reacts to such administrative penalties? Some studies found that shareholders' benefits will be negatively affected by accidental events [3-7]. The researchers found that the disclosure of environmental violation events will lower corporate estimated value [5, 8-10]. However, some researchers have come to different conclusions [11, 12].

It then brings up a new question: What are the functions of environmental penalty disclosure? Penalty announcements provide a way to get a complete understanding of a company's situation to the stakeholders and the investors. In such an announcement, planned solutions and possible influences of a penalty for a company should be clearly stated for shareholders' decision-making. The penalty announcement is also a way to internalize the negative externalities of the environment and exerts deterrent effects [7, 13]. Besides, the legitimacy of corporate will be damaged by environmental penalties. Environmental information disclosure is also identified as a positive strategy to address legitimate crisis [14], which also helps to resolve penalty issues to avoid other substantive negative influence.

Whether the penalty announcement damages a corporate market value has remained empirically elusive and controversial due to the following reasons. First, impacts of information disclosure cannot be properly observed because it is not separated from the penalty itself. Second, some disclosures are conducted by media and environmental agencies of the government instead of themselves.

In China, most of the penalties were imposed by the municipal environmental protection department, so this paper takes listed companies who received municipal environmental penalties (i.e., lower than provincial level) as research samples to observe how the stock market reacts to such environmental penalties. Further, according to the Regulation on Information Disclosure of Listed Companies, the company that is subject to the punishment of the environmental protection department above the provincial level must make the penalty announcement. To estimate the effects of actively self-disclosure of penalty information on the companies' market values, this study focuses on listed companies with municipal-level penalties. This study can provide a reference for listed companies and investors to understand the economic impact of environmental penalty announcements. It also provides policy implications for the government to establish and improve related regulations and bylaws in environmental governance.

\section{Material and Methods}

\section{Literature Review and Hypotheses Development}

According to the efficient market hypothesis, the latest information will be reflected in the stock price, both positive and negative latest information will cause abnormal fluctuations in the stock price. Based on the efficient market hypothesis, researchers used the event study methodology to examine the impact of various adverse environmental events on the stock market, and found that the market will have a negative response to negative environmental events $[4,9,15,16]$. However, some researchers have come to different conclusions $[12,17]$. These relevant studies have two lines, one is the news media exposure and the market's reaction, and the other line is the government disclosure and the market's reaction. Researchers have found that negative environmental events exposed or reported by the news media react negatively to the share prices of listed firms [13, 18]. However, Jones and Rubin found an insignificant overall drop in market value following environmental accidents [11]. Some studies revealed that negative environmental events issued by government environmental protection departments can have a negative impact on the company's market value $[5,8]$. For example, Xu et al. found that the stock market response to environmental violations in China was not as strong as that in other countries. They argued that negative environmental events have little impact on the stock market [3]. Besides, Zhe et al. found that the market reacts negatively after the self-disclosure of work safety accidents [19].

In the academic literature on the stock market's reactions to negative environmental events, several studies group together major accidents and minor incidents, and others group together negative environmental events that were disclosed by news media and events disclosed by the government. The heterogeneity of samples may make the conclusions drawn by different researchers different. Besides, in the study of the functions and values of environmental information disclosure, some researchers argued that environmental information disclosure is beneficial to firm value [20-25], while others believed that 
environmental information disclosure has a negative impact on firm value $[11,12]$. The current research has not yet revealed the functions and values of selfdisclosure of environmental penalty information.

Environmental violation means that a company cannot meet the minimum legal requirements for its pollution control. In this case, investors will anticipate that companies will have to increase their investment in environmental protection to meet minimum environmental requirements stipulated by the law in the future. Therefore, information about environmental violations will make investors adjust their investment decisions. Besides, corporate environmental violations increases corporate credit risk and information risk, and makes external financing more difficult [26]. In addition, they will also cause losses to the market value of the equity or the wealth of the shareholders [18, 27-29].

In a stock market with incomplete information, the buyer and the seller in the trade do not have equal access to relevant information. Due to the asymmetry of information, the amount of punished information obtained by different investors is different, and the time for obtaining punished information is different too. Existing studies provide evidence that before receiving the notice of administrative penalty from the regulator, information about a company's penalty has usually been leaked in advance [3]. Shareholders or some investors of a listed company may use their superiority of access to information to receive some unpublished negative information and sell their shares of the company in advance, which causes the falling of stock return. Therefore, this paper proposes below hypothesis 1 .

H1: Stock returns of listed companies with penalties will fall before they are subject to administrative penalties.

In a crisis of environmental penalty, self-disclosing environmental penalty information is useful for the punished company to accept or reject responsibility explicitly [30]. Besides, self-disclosing environmental penalty information in the announcement is the conduit for disseminating price-sensitive information [31]. Researchers found that companies who chose to hide environmental information often face higher environmental risks, resulting in higher financing costs and additional environmental risk returns demanded by investors [32]. On the contrary, self-disclosing negative information can not only enhance the reliability of the information disclosed by a company, but also mitigate environmental risks and reduces the risk premium borne by shareholders [33]. Researches based on the frame theory found that timely communication with the public enabled companies to describe the crisis in their own terms which could be helpful to ease the severity of a crisis $[30,34]$. But, the later a company communicates with the public after a crisis, the less persuasive of the information being disclosed [34].

Investors and shareholders wish to get real and timely penalty information for their investment reference. The self-disclosure of the environmental penalty is not only a way to reduce environmental risks and mitigate the crisis, but also a favorable choice to avoid the decline in stock returns due to the continuous fermentation of the penalized accidents. Therefore, this paper proposes below hypothesis 2 .

H2: Self-disclosing environmental penalty information can reduce the negative impact of the penalty on a company's shares and help the stock return rebound.

The value of environmental information is that investors regard the lack of environmental information as environmental management risk [33, 35]. The concealment of some important information at the end of a year will lead to the increase of information cost for investors or the insufficiency of information needed for investment decision-making, which increases the uncertainty of the investment environment [36]. In the meantime, it restrains investment enthusiasm, reduces the trading volume and leads investors to sell off shares. However, positive information can affect the confidence of investors and cause a positive market reaction, resulting in prospective excess earnings and increased trading volume $[10,37]$. Besides, the disclosure of environmental information can generate benefits for companies by helping them mitigate potential harm from negative events [38].

In a crisis of environmental penalty, the announcement provides the company with an opportunity to explain the fact and present the company's active and effective solution to illegal problems. The rectifications and the statements affected the company's operation in the announcement will help to reduce the panic of investors and mitigate possible economic risks caused by information asymmetry. Therefore, this paper proposes below hypothesis 3 .

H3: More detailed disclosure in the announcements will boost the company's stock return.

\section{Data Sources}

The self-disclosure of environmental penalty information refers to the announcement made by the listed company after receiving the notice of administrative punishment issued by the municipal environmental protection department. This paper selects Shanghai and Shenzhen A-share listed companies that were punished by municipal environmental protection departments from 2014 to 2017. We excluded companies that had no trading data in 10 trading days since the date of the event and we ruled out companies involved in significant events such as M\&A and restructuring and earnings preannouncement occurred within 15 trading days before and after the event. Data on the environmental penalty of listed companies are from the database of IPE. Environmental penalty announcements were obtained on the website of China Environmental News or the official website of the company. Both websites are the platform of the 
company's self-disclosure penalty information. Finally, 431 cases of environmental penalties are obtained, but only 72 of them released environmental penalty announcements. The financial data are from the CSMAR Database. Data processing and calculation in this paper are mainly conducted by statistical software SPSS 21 and Stata 15.

\section{Methods}

This paper adopts the event study method to test the financial market's response to environmental penalty information. The event study method was initiated by Ball \& Brown and Fama et al. [39, 40]. The principle of this method is to explain the effect of a specific event on the stock price and rate of return, by studying the changes of the stock returns of the sample before and after the event.

The event study method is based on the hypothesis of efficient market, that is, the stock price reflects the known public information. Since investors are rational and investors' reactions to new information are also rational, we can get the abnormal returns by eliminating the estimated normal returns from the actual stock returns. Abnormal returns can measure the extent to which stock prices react abnormally to events or information disclosure.

In this study, the time when a listed company released an announcement of the environmental penalty is considered as an event day. The period during which self-disclosure of announcement affects the company's stock return is called an event window. The period before the event window when stock returns are not affected by penalty information is called the estimation window, in which the sample company's stock return data are used to estimate model parameters.

With regard to the selection of event windows, scholars usually use 41 trading days $(-20,20)$ [3], 31 trading days $(-10,20)[4]$ and 45 trading days $(-15,29)$ [19]. The length of the event window is defined as 41 days in this paper, including 20 trading days before and after the listed company releases the environmental penalty announcements. Referring to the research by Godfrey et al. and Zhe et al. , this paper uses 120 trading days in front of the event window as an estimation window to estimate expected returns [19, 41].

The daily average return of the sample companies is calculated by the company's daily closing price, and the

Table 1. T-test of CAAR in the window period.

\begin{tabular}{|c|c|c|c|c|c|c|c|}
\hline Day & Total & Penalized & Self-Disclosed & Day & Total & Penalized & Self-Disclosed \\
\hline-20 & 0.00051 & 0.00135 & -0.00651 & 1 & $0.00220 * * *$ & $0.00203 * * *$ & $0.00355^{* *}$ \\
\hline-19 & 0.00214 & 0.00260 & -0.00168 & 2 & $0.00404 * * *$ & $0.00428 * * *$ & $0.00198 * * *$ \\
\hline-18 & 0.00251 & 0.00294 & -0.00111 & 3 & $0.00207 * * *$ & $0.00244 * * *$ & $-0.00110 * * *$ \\
\hline-17 & $0.00160 *$ & $0.00160 *$ & 0.00161 & 4 & $0.00114 * * *$ & $0.00116^{* * *}$ & $0.00089 * * *$ \\
\hline-16 & 0.00311 & 0.00327 & 0.00180 & 5 & $0.00030^{* * *}$ & $0.00016^{* * *}$ & $0.00144 * * *$ \\
\hline-15 & $0.00265 *$ & 0.00293 & 0.00035 & 6 & $0.00035^{* * *}$ & $0.00013 * * *$ & $0.00215^{*}$ \\
\hline-14 & $0.00072 *$ & $0.00065^{*}$ & 0.00125 & 7 & $-0.00047 * * *$ & $-0.00069 * * *$ & $0.00131 * * *$ \\
\hline-13 & $-0.00180 *$ & $-0.00226^{*}$ & 0.00199 & 8 & $0.00117 * * *$ & $0.00080^{* * *}$ & $0.00422 * * *$ \\
\hline-12 & $-0.00167 *$ & -0.00252 & $0.00542 *$ & 9 & $0.00198 * * *$ & $0.00184 * *$ & $0.00311 * * *$ \\
\hline-11 & $-0.00298^{*}$ & $-0.00413^{*}$ & $0.00657^{*}$ & 10 & $0.00150^{* * *}$ & $0.00132 * * *$ & $0.00296 * * *$ \\
\hline-10 & $-0.00306^{*}$ & $-0.00384 *$ & $0.00338^{*}$ & 11 & $0.00052 * * *$ & $-0.00005^{* * *}$ & $0.00524 * *$ \\
\hline-9 & $-0.00296 * *$ & $-0.00335^{* *}$ & $0.00025^{*}$ & 12 & $-0.00096^{* * *}$ & $-0.00188 * * *$ & $0.00669 * *$ \\
\hline-8 & $-0.00363 * *$ & $-0.0043 * *$ & $0.00193 * *$ & 13 & $-0.00330 * * *$ & $-0.00453 * * *$ & $0.00706^{* *}$ \\
\hline-7 & $-0.00418 * *$ & $-0.00478 * *$ & $0.00082 * *$ & 14 & $-0.00445^{* * *}$ & $-0.00551 * *$ & $0.00447 *$ \\
\hline-6 & $-0.00567 * * *$ & $-0.00591 * *$ & $-0.00367 * *$ & 15 & $-0.00509 * * *$ & $-0.00608 * *$ & $0.00322 *$ \\
\hline-5 & $-0.00557 * * *$ & $-0.00573 * *$ & $-0.00427 * *$ & 16 & $-0.00393 * *$ & $-0.00491 *$ & 0.00430 \\
\hline-4 & $-0.00643 * *$ & $-0.00656^{* *}$ & $-0.00536^{* *}$ & 17 & $-0.00336^{*}$ & $-0.00428^{*}$ & 0.00434 \\
\hline-3 & $-0.00688 * *$ & $-0.00710 * *$ & $-0.00509 * *$ & 18 & $-0.00206^{*}$ & -0.00287 & 0.00480 \\
\hline-2 & $-0.00443 * * *$ & $-0.00506^{* *}$ & $0.00078 * *$ & 19 & -0.00075 & -0.00147 & 0.00407 \\
\hline-1 & $0.00031 * *$ & $0.00014 * *$ & $0.00168 * * *$ & 20 & 0.00055 & -0.00007 & 0.00365 \\
\hline 0 & $0.00263 * * *$ & $0.00234 * *$ & $0.00508 * *$ & & & & \\
\hline
\end{tabular}

$*, * *$ and $* * *$ indicate significance level of $0.1,0.05$ and 0.01 , respectively. 
daily average return of the market is calculated by the Shanghai Composite Index as follows:

$$
\begin{gathered}
R_{i t}=P_{i t}-P_{i, t-1} / P_{i, t-1} \\
R_{m t}=P_{m t}-P_{m, t-1} / P_{m, t-1}
\end{gathered}
$$

...where, $\left(P_{i t}\right)$ represents the t-day closing price of individual stocks, $\left(R_{i t}\right)$ is the t-day average yield of individual stocks, $\left(P_{m t}\right)$ reflects the Shanghai Composite Index on the t-day of the market and $\left(R_{m t}\right)$ is the t-day average return of the market.

The expected return rate is calculated by the market model. Using the historical return rate of stock $i$ in the estimated period and the corresponding market portfolio return rate, we can get the coefficient $\beta_{i}$ and the constant term $\alpha_{i}$ of stock i. Further, we calculate the expected normal return rate of sample companies in the event period through the Eq. 3 .

$$
R_{i t}=\alpha_{i}+\beta_{i} R_{m t}+\varepsilon_{i t}
$$

...where, $\left(\alpha_{i}\right)$ represents the constant term, $\left(\beta_{i}\right)$ represents the systematic risk of stock $\mathrm{i}$, and $\left(R_{m t}\right)$ represents the real return of the market portfolio at time t, respectively. $\left(\varepsilon_{i t}\right)$ is the residual term.

The calculation formulas of abnormal return (AR), average abnormal return (AAR), cumulative abnormal return (CAR), and cumulative average abnormal return (CAAR) are as follows:

$$
\begin{gathered}
A R_{i t}=R_{i t}-E R_{i t} \\
A A R_{i t}=\frac{1}{N} \sum_{i=1}^{n} A R_{i t} \\
C A R_{i t}=\sum_{t=t_{1}}^{t=t_{2}} A R_{i t}
\end{gathered}
$$

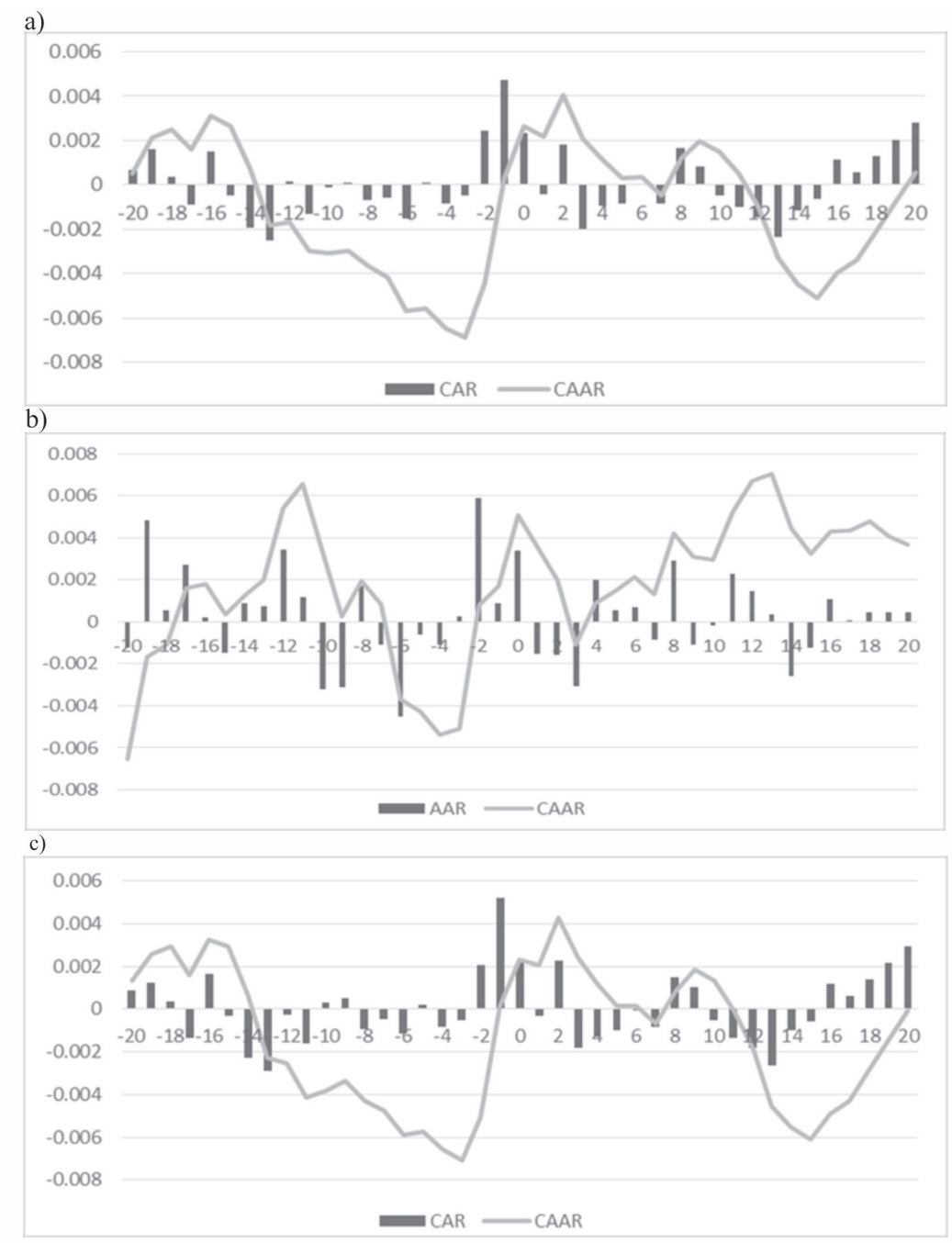

Fig. 1. a) The trend of CAAR for penalized companies as a whole; b) The trend of CAAR for companies with penalty self-disclosure; c) The trend of CAAR for companies without penalty self-disclosure. 
Table 2. Variable description.

\begin{tabular}{|c|c|c|c|}
\hline Category & Variable Name & Symbol & Description \\
\hline $\begin{array}{l}\text { Explained } \\
\text { variable }\end{array}$ & Cumulative abnormal return & CAR & $C A R_{[-15,15]}, C A R_{[-10,10]}, C A R_{[-5,5]}, C A R_{[-3,3]}$ \\
\hline \multirow{3}{*}{$\begin{array}{l}\text { Explanatory } \\
\text { variables }\end{array}$} & Self-disclosure & SD & Self-disclosure is coded 1 , otherwise 0 \\
\hline & $\begin{array}{l}\text { Self-disclosure of rectification } \\
\text { measures }\end{array}$ & $\begin{array}{l}\text { RMS, } \\
\text { RMD }\end{array}$ & $\begin{array}{l}\text { Three categories: No mention; Brief mention (RMS); proposed a } \\
\text { specific rectification measure (RMD). We set two dummy variables. }\end{array}$ \\
\hline & $\begin{array}{l}\text { Self-disclosure of impacts of } \\
\text { penalties on its operation and } \\
\text { production }\end{array}$ & IPS, IPD & $\begin{array}{l}\text { Three categories: No mention; Brief mention (IPS); Disclose in detail } \\
\text { the impacts of penalties on its operation and production (IPD). We set } \\
\text { two dummy variables. }\end{array}$ \\
\hline \multirow{6}{*}{$\begin{array}{l}\text { Controlled } \\
\text { variables }\end{array}$} & $\begin{array}{l}\text { Rate of return on common } \\
\text { stockholders' equity }\end{array}$ & ROE & Net profit / Balance of shareholders' equity \\
\hline & Asset-liability ratio & DEBET & Liabilities / Total assets \\
\hline & Company size & SIZE & Natural logarithm of total assets at the end of the year \\
\hline & The ratio of outstanding shares & TRADE & Circulating shares / Total shares \\
\hline & $\begin{array}{l}\text { The ratio of state-owned } \\
\text { shares }\end{array}$ & STATE & State-owned shares / Total shares \\
\hline & Year & YEAR & Dummy variable \\
\hline
\end{tabular}

$$
C A A R_{\left[t_{1}, t_{2}\right]}=\sum_{t=t_{1}}^{t=t_{2}} A A R
$$

...where, $R_{i t}$ represents the real rate of return of stock $i$ on t-day and the $E R_{i t}$ is estimated expected rate of return. $A R_{i t}$ represents the abnormal return of stock $\mathrm{i}$ on $\mathrm{t}$-day. $A A R_{i t}$ is the average abnormal return of $\mathrm{N}$ stocks on t-day. $C A R_{i t}$ represents the cumulative abnormal return of stock i. $C C A R_{\left[t_{1}, t_{2}\right]}$ represents the cumulative average abnormal return of $\mathrm{N}$ stocks from time $t_{1}$ to $t_{2}$.

\section{Results and Discussion}

Analysis of CAAR

\section{T-test of CAAR in the Window Period}

The study divides the samples into two categories, including companies that do not disclose penalty information and the others. Table 1 shows the T-test of CAARs of listed companies receiving environmental penalties during the window period. It can be seen from Table 1 that most of the CAARs are significant at 0.1 level in $[-14,14]$ period, indicating that the stock return of the listed company has been significantly affected about 14 days before and after the environmental penalty. Besides, the stock market cannot react to the punishment of environmental violations in a more extended period.

\section{Trend Analysis of CAAR}

The response trend of the stock market to environmental penalties is shown in Fig. 1. It can be seen from Table 1 and part (a) of Fig. 1 that the CAAR shows a downward trend at the significance level of 0.1 from $\mathrm{T}=-15$ to $\mathrm{T}=-3$. The results validate hypothesis 1 that the company's share return will fall before it is subject to environmental penalties. This outcome not only indicates that environmental administrative penalties have a negative impact on the stock market but also demonstrates that the environmental violation information has been leaked before the environmental protection department decides the administrative penalty.

As shown in Fig. 1, trends of CAAR changes in part (b) and part (c) are obviously different. As shown in part (b) of Fig. 1, for companies with self-disclosure, CAAR shows a downward trend from $\mathrm{T}=-10$ to $\mathrm{T}=-4$, then keeps rising from $\mathrm{T}=-3$ to $\mathrm{T}=0$, followed by a three-day decline, and then continues to rise in volatility. As shown in part (c) of Fig. 1, for those penalized companies without penalty self-disclosure, CAAR shows a downward trend from $\mathrm{T}=-15$ to $\mathrm{T}=-3$, and an upward trend from $\mathrm{T}=-2$ to $\mathrm{T}=0$, then shows a downward trend in $\mathrm{T}=1$, but then fluctuates downwards until CAAR becomes negative.

For companies without penalty self-disclosure, after a small rise in CAAR, then the CAAR continues to decline in volatility. However, for companies with selfdisclosure, the CAAR fluctuates upwards during the window period after a slight decline. Finally, at the end of the window period, the value of CAAR becomes positive in part (b) of Fig. 1, while negative in part (c) of Fig. 1.

As shown in part (b) of Fig. 1 and Table 1, during $\mathrm{T}=-12$ to $\mathrm{T}=15$, CAAR is significant at the level of 0.1 in t-test, indicating that although the stock return of a company with self-disclosure fell out for a short period, it does not decrease but increase during the 


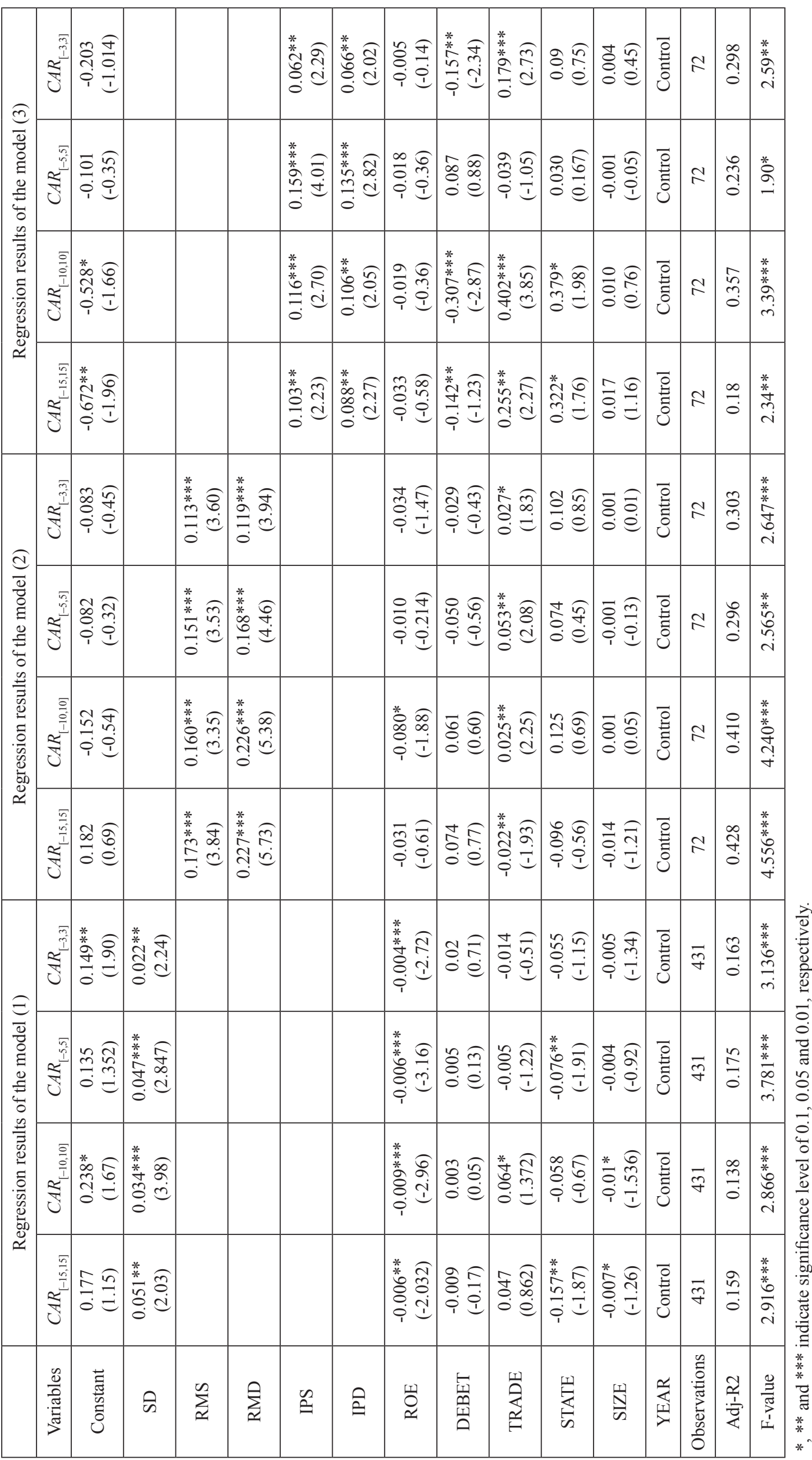


event window. This finding supports hypothesis 2 that the self-disclosure of the environmental penalty helps the stock returns to rebound and to reduce the negative impact of the environmental penalty on companies' market value.

\section{Regression Analysis}

\section{Variable Define}

We used a multivariate linear model to examine the impact of environmental penalty announcements on cumulative abnormal returns of penalized companies. This paper takes the cumulative abnormal return rate of sample companies as the explained variable and sets four explained variables, namely $C A R_{[-15,15]}$, $C A R_{[-10,10]}, C A R_{[-5,5]}$, and $C A R_{[-3,3]}$. Explanatory variables were set according to whether a company discloses its environmental penalties and the detailed degree of the content disclosed. We set five explanatory variables, namely SD, RMS, RMD, IPS, and IPD.

Based on scholars' research on the response of stock return to negative events $[3,31,42]$, this study considers the impact of company size, ownership structure and financial situation on stock price volatility, and takes company size, rate of return on common stockholders' equity, asset-liability ratio, circulating share ratio and state-owned share ratio as control variables. Descriptions of variables are shown in Table 2.

\section{Regression Analysis between Self-Disclosure and $C A R s$}

The regression model (1) is constructed to test the impacts of self-disclosure of the environmental penalty on the cumulative abnormal return of companies. The regression model (2) and model (3) are constructed to investigate the effects of the contents of environmental penalty disclosure on cumulative abnormal return. The regression results for the model (1), model (2) and model (3) are shown in Table 3.

$$
\begin{aligned}
& C A R=\beta_{0}+\beta_{1} S D+\beta_{2} R O E+\beta_{3} D E B E T+\beta_{4} T R A D E+\beta_{5} S T A T E \\
& +\beta_{6} S I Z E+\beta_{7} Y E A R+\varepsilon
\end{aligned}
$$

$C A R=\beta_{0}+\beta_{1} R M S+\beta_{2} R M D+\beta_{3} R O E+\beta_{4} D E B E T+\beta_{5} T R A D E$ $+\beta_{6} S T A T E+\beta_{7} S I Z E+\beta_{8} Y E A R+\varepsilon$

$$
C A R=\beta_{0}+\beta_{1} I P S+\beta_{2} I P D+\beta_{3} R O E+\beta_{4} D E B E T+\beta_{5} T R A D E
$$$$
+\beta_{6} S T A T E+\beta_{7} S I Z E+\beta_{8} Y E A R+\varepsilon
$$

According to the regression results of the model (1), the CARs $\left(C A R_{[-15,15]}, C A R_{[-10,10]}, C A R_{[-5,5]}, C A R_{[-3,3]}\right)$ are positively correlated with the penalty announcement (SD), and are significant at the level of 0.05 .
The above empirical results show that penalized companies who disclose their environmental penalty information have higher cumulative abnormal returns. This verifies hypothesis 2, that is, self-disclosing environmental penalty information helps to reduce the negative impacts of environmental penalties on the company's stock returns and to improve the stock returns to some degree.

In regression (2) and regression (3), the samples are those companies with penalty announcements. According to the regression results of the model (2) in Table 3, CAR $R_{[-15,15]}, C A R_{[-10,10]}, C A R_{[-5,5]}$ and $C A R_{[-3,3]}$ are all significantly and positively correlated with RMS (0.173, $\mathrm{p}<0.01 ; 0.160, \mathrm{p}<0.01 ; 0.151, \mathrm{p}<0.01$; $0.113, \mathrm{p}<0.01)$ and $\operatorname{RMD}(0.227, \mathrm{P}<0.01 ; 0.226, \mathrm{p}<0.01$; $0.168, \mathrm{p}<0.01 ; 0.119, \mathrm{p}<0.01)$, respectively. Besides, coefficients of RMD are all larger than those of RMS. The results indicate that the cumulative abnormal returns of companies that disclose rectification measures are positively affected, and the detailed disclosure of rectification measures does not reduce the cumulative abnormal returns. These empirical results verify hypothesis 3 .

According to the regression results of the model (3) in Table 3, CAR $R_{[-15,15]}$ is significantly and positively correlated with the coefficients of IPS $(0.103, \mathrm{p}<0.05)$ and IPD $(0.088, \mathrm{p}<0.05)$. After adjusting the event window, we find that $C A R_{[-10,10]}, C A R_{[-5,5]}$ and $C A R_{[-3,3]}$ are also significantly and positively correlated with IPS (0.116, $\mathrm{p}<0.01 ; 0.159, \mathrm{p}<0.01 ; 0.062, \mathrm{p}<0.01)$ and IPD (0.106, $\mathrm{p}<0.05 ; 0.135, \mathrm{p}<0.01 ; 0.066, \mathrm{p}<0.05)$, and the coefficients of IPS are all lager than those of IPD.

These results indicate that the cumulative abnormal returns of companies are positively affected by the self-disclosure of the impact of penalties in the announcements. Besides, detailed disclosure of such information does not reduce the company's stock returns but helps to boost its stock returns. Hence, the regression results validate hypothesis 3 .

\section{Conclusions}

To reveal the reaction of the stock market to the environmental administrative penalties and the impact of self-disclosure of the environmental penalty information on the stock return. In this paper, the reaction of the stock market before and after the penalty announcements is analyzed by the event study method. Multiple regression analyses verify the impact of selfdisclosure of the environmental penalty on the stock return in a window period. Specific research findings are as follows:

First, this study provides evidence that environmental administrative penalties have a negative impact on the stock market. The negative effect is ahead of time because stock returns begin to fall before the penalty announcements. Specifically, stock returns continue to fall after a short while of rebound several days 
before the announcements. Before the Environmental Protection Bureau imposes administrative penalties on listed companies in China, it needs a period to investigate and collect evidence of companies' violation actives. It is reasonably speculated that the information on a company's impending penalty has been leaked ahead of time. The main reason for the advanced fall of stock returns is that some alert and resourceful investors tend to sell their stock shares based on some inside information.

Second, this study finds that after the listed companies have been subjected to administrative penalties of municipal environmental protection departments, the self-disclosure of environmental penalty information helps to reduce the negative impacts of environmental penalties on a company's stock return. Previous studies indicated that disclosure of environmental violations by environmental protection authorities or media could lead to a decline in stock returns $[3,5,13,18]$. However, the results indicate that self-disclosure of environmental penalty information will not damage the company's market value, which is different from the previous research conclusions.

Third, these results show that disclosing the information of rectification measures and the impacts of penalties on operation and production are good for the stock returns, and disclosing this related penalty information in detail will not reduce the stock returns but help to enhance its market value. Because the information that a company will be punished has been leaked ahead of the announcement of the environmental penalty. We argue that the disclosure of rectification measures and the disclosure of impacts of penalties will help to alleviate the harmful effects of the punishment crisis. This study provided valuable insights that the disclosure of environmental penalty information is not the reason for the decline of stock return, and the real reason may be that the penalized companies do not disclose information about environmental penalties. The results provide evidence that under the condition of punishment by the municipal environmental protection department, the self-disclosure of environmental penalty information and the detailed description of the rectification measures and impacts of penalty taken by companies will help to reduce the severe economic risks and losses that may be caused by the information risk. Besides, the self-disclosure of penalty information cannot lead to the punitive decline of its stock return but can help to mitigate the corresponding crisis.

\section{Implications}

This study reveals that the disclosure of penalty information plays an important economic role in reducing the negative impacts of penalties on stock returns, which will help researchers in related fields to understand the economic value of self-disclosing environmental penalty information and its significance.
Besides, the findings can provide guidance for corporate environmental information disclosure. After being punished by the environmental protection department, the self-disclosure of penalty information is not only a way to reduce environmental risks and mitigate crises, but also a favorable choice to avoid continuous fermentation of penalty events and then cause economic losses.

This study also provides policy implications for the regulation of information disclosure of listed companies in China. Failure of the penalized company to disclose the environmental penalty information harms the interests of some uninformed investors. Therefore, this paper suggests that capital market regulators should formulate relevant laws and regulations to stipulate that local environmental protection departments should also fulfill their supervisory responsibilities regarding the self-disclosure of environmental penalty information, to ensure that all investors have the opportunity to understand the company's penalty situation in time. From the view of policy-making, the self-disclosure of penalty information cannot lead to the punitive decline of its stock return. On the contrary, it is used by penalized listed companies to alleviate the specific crisis, which reflects the failure of the existing environmental information disclosure policy of listed companies in China to a certain extent.

In the future, it will be necessary to expand the research period and increase the numbers of samples to evaluate the economic impact of the announcement. Besides, the samples selected in this study come from listed companies penalized by environmental protection departments below the provincial level. For listed companies penalized by environmental protection departments at or above the provincial level, the economic impact of the environmental penalty announcement needs to be further tested.

\section{Acknowledgements}

This research was funded by the National Natural Science Foundation of China Project, Grant number 71473029, 71974028; National Natural Science Foundation of China International (regional) Joint Research Project, Grant number 71320107006. Thanks to the NSFC's support for our research.

\section{Conflict of Interest}

The authors declare no conflict of interest.

\section{Reference}

1. MANAGI S., KANEKO S. Environmental performance and returns to pollution abatement in China. Ecol. Econ, 68 (6), 1643, 2009. 
2. DIAO X.D., ZENG S.X., TAM C.M., TAM V.W.Y. EKC analysis for studying economic growth and environmental quality: a case study in China. J. Clean. Prod, 17 (5), 541, 2009.

3. XU X.D., ZENG S.X., TAM C.M. Stock market's Reaction to Disclosure of Environmental Violations: Evidence from China. J. Bus. Ethics, 107 (2), 227, 2012.

4. CAPELLE-BLANCARD G., LAGUNA M.A. How does the stock market respond to chemical disasters? J. Environ. Econ. Manage, 59 (2), 192, 2010.

5. DASGUPTA S., HONG J.H., LAPLANTE B., MAMINGI N. Disclosure of environmental violations and stock market in the Republic of Korea. Ecol. Econ, 58 (4), 759, 2006.

6. HAMILTON J.T. Pollution as News: Media and Stock Market Reactions to the Toxics Release Inventory Data. J. Environ. Econ. Manage, 28 (1), 98, 1995.

7. LAPLANTE B., LANOIE P. The Market Response to Environmental Incidents in Canada: A Theoretical and Empirical Analysis. South. Econ. J, 60 (3), 657, 1994.

8. DASGUPTA S., LAPLANTE B., MAMINGI N. Pollution and capital markets in developing countries. J. Environ. Econ. Manage, 42 (3), 310, 2001.

9. HUANG H., WU D., J, G. Chinese shareholders' reaction to the disclosure of environmental violations: a CSR perspective. Int. J. Corp. Soc. Responsib, 2 (1), 12, 2017.

10. YANG J., LU W., ZHOU C. The immediate impact of purchasing/sales contract announcements on the market value of firms: An empirical study in China. Int. J. Prod. Econ, 156, 169, 2014.

11. JONES K., RUBIN P.H. Effects of harmful environmental events on reputations of firms. Advances in Financial Economics, 6, 161, 2001.

12. SCHOLTENS B., BOERSEN A. Stocks and energy shocks: The impact of energy accidents on stock market value. Energy, 36 (3), 1698, 2011.

13. CARPENTIER C., SURET J.M. Stock market and deterrence effect: A mid-run analysis of major environmental and non-environmental accidents. J. Environ. Econ. Manage, 71, 1, 2015.

14. ISLAM M.A., DEEGAN C. Motivations for an organisation within a developing country to report social responsibility information Evidence from Bangladesh. Accounting, Audit. Account. J, 21 (6), 850, 2008

15. LUNDGREN T., OLSSON R. Environmental incidents and firm value - international evidence using a multi-factor event study framework. Appl. Financ. Econ, 20 (16), 1293, 2010.

16. GREWAL J., RIEDL E., SERAFEIM G. Market Reaction to Mandatory Nonfinancial Disclosure. Manage. Sci, 65 (7), 3061, 2018.

17. RAMIAH V., MARTIN B., MOOSA I. How does the stock market react to the announcement of green policies? J. Bank. Financ, 37 (5), 1747, 2013

18. XU X.D., ZENG S.X., ZOU H.L., SHI J.J. The Impact of Corporate Environmental Violation on Shareholders' Wealth: A Perspective Taken from Media Coverage. Bus. Strateg. Environ, 25 (2), 73, 2016.

19. ZHE O., WEI J., ZHAO D. Stock market's reaction to selfdisclosure of work safety accidents: an empirical study in China. Qual. Quant, 51 (4), 1611, 2017.

20. GRIFFIN P.A., SUN Y. Going green: Market reaction to CSRwire news releases. J. Account. Public Policy, 32 (2), 93, 2013.
21. RADHOUANE I., NEKHILI M., NAGATI H., PACHÉ G. The impact of corporate environmental reporting on customer-related performance and market value. Manag. Decis, 56 (7), 1630, 2018.

22. LEE S.Y., PARK Y.S., KLASSEN R.D. Market responses to firms' voluntary climate change information disclosure and carbon communication. Corp. Soc. Responsib. Environ. Manag, 22 (1), 1, 2015.

23. ZHOU T., XIE J., LI X. Financial Reporting Quality and Idiosyncratic Return Volatility: Evidence from China. Emerg. Mark. Financ. Trade, 53 (4), 835, 2017.

24. STONE M., ERICKSON S.L., THORWICK M. An examination of Pfizer's crisis communication strategies in the Celebrex case. Am. J. Manag, 15 (1), 11, 2015.

25. FREEDMAN M., PATTEN D.M. Evidence on the pernicious effect of financial report environmental disclosure. Accounting Forum, 28 (1), 27, 2004.

26. CHEN Y., ZHU S., WANG Y. Corporate fraud and bank loans: Evidence from China. China J. Account. Res, 4 (3), 155,2011

27. GUPTA S., GOLDAR B. Do stock markets penalize environment-unfriendly behaviour? Evidence from India. Ecol. Econ, 52 (1), 81, 2005

28. KARPOFF J.M., LOTT J. ., WEHRLY E.W. The reputational penalties for environmental violations: empirical evidence. The Journal of Law and Economics, $48(2), 653,2005$.

29. JOHNSON W.C., XIE W., YI,S. Corporate fraud and the value of reputations in the product market. J. Corp. Financ, 25, 16, 2014.

30. CLAEYS A.S., CAUBERGHE V. Crisis response and crisis timing strategies, two sides of the same coin. Public Relat. Rev, 38 (1), 83, 2012.

31. YEKINI L.S., WISNIEWSKI T.P., MILLO Y. Market reaction to the positiveness of annual report narratives. $\mathrm{Br}$. Account. Rev, 48 (4), 415, 2016.

32. FERNÁNDEZ-KRANZ D., SANTALÓ J. When necessity becomes a virtue: the effect of product market competition on corporate social responsibility. J. Econ. Manag. Strateg, 19 (2), 453, 2010.

33. KUO L., CHEN V.Y.J. Is environmental disclosure an effective strategy on establishment of environmental legitimacy for organization? Manag. Decis, 51 (7), 1462, 2013.

34. ARPAN L.M., ROSKOS EWOLDSEN, D. R. Stealing thunder: Analysis of the effects of proactive disclosure of crisis information. Public Relat. Rev, 31 (3), 425, 2005.

35. CLARKSON P.M., FANG X., LI Y., RICHARDSON, G. The relevance of environmental disclosures: Are such disclosures incrementally informative? J. Account. Public Policy, 32 (5), 410, 2013.

36. DELANEY L., THIJSSEN J.J.J. The impact of voluntary disclosure on a firm's investment policy. Eur. J. Oper. Res, 242 (1), 232, 2015.

37. RAJGOPAL S., VENKATACHALAM M. Financial reporting quality and idiosyncratic return volatility. J. Account. Econ, 51, 1, 2011.

38. PELOZA J. Using corporate social responsibility as insurance for financial performance. Calif. Manage. Rev, 48 (2), 52, 2006.

39. BALL R., BROWN P. An empirical evaluation of accounting income numbers. J. Account. Res, 6 (2), 159, 1968.

40. FAMA E.F., FISHER L., JENSEN M.C., ROLL R. The adjustment of stock prices to new information. Int. Econ. Rev, 10 (1), 1, 1969. 
41. GODFREY P.C., MERRILL C.B., HANSEN J.M. The relationship between corporate social responsibility and shareholder value: an empirical test of the risk management hypothesis. Strateg. Manag. J, 30 (4), 425, 2009.
42. JORY S.R., NGO T.N., WANG D., SAHA A. The market response to corporate scandals involving CEOs. Appl. Econ, 47 (17), 1723, 2015. 